Department of Economics- FEA/USP

\title{
Does the Concern About Local Crime Affect Trust in the Police?
}

\author{
JoElson Oliveira SaMpaio \\ RODRigo De-LosSo da Silveira Bueno \\ LuCIANA Grosso CUNHA \\ RENAN GOMES DE PIERI
}

WORKING PAPER SERIES № 2015-19 


\author{
DEPARTMENT OF ECONOMICS, FEA-USP \\ WORKING PAPER № 2015-19
}

\title{
Does the Concern About Local Crime Affect Trust in the Police?
}

\author{
Joelson Oliveira Sampaio (joelsonssp@gmail.com) \\ Rodrigo De-Losso (delosso@usp.br) \\ Luciana Gross Cunha (luciana.cunha@fgv.br) \\ Renan Gomes de Pieri
}

\begin{abstract}
:
This paper investigates local crime's concern effect on confidence in the police using Two Least Square Regressions having as instrumental variable the individual distance to police stations. We explore data from the Confidence in Justice Survey conducted for the period at 2013 to 2014 at state of Sao Paulo. We find that an increase at the total crimes registered reduces confidence on police. Such results are more effusively in some crimes like drug dealing and rape. Exploring heterogeneities in the results we find that black are more sensitive to crime rate changes even living in similar neighborhoods in what respect to security. Results also show that who has already had prior experience with the police is less sensitive independently of the quality of police job at the time.
\end{abstract}

Keywords: Trust in the Police, Institutions, Criminality.

JEL Codes: . 


\title{
DOES THE CONCERN ABOUT LOCAL CRIME AFFECT TRUST IN THE POLICE?
}

\author{
Joelson Oliveira Sampaio ${ }^{1}$ \\ Rodrigo De Losso da Silveira Bueno \\ Luciana Gross Cunha ${ }^{3}$ \\ Renan Gomes De Pieri ${ }^{4}$
}

\begin{abstract}
This paper investigates local crime's concern effect on confidence in the police using Two Least Square Regressions having as instrumental variable the individual distance to police stations. We explore data from the Confidence in Justice Survey conducted for the period at 2013 to 2014 at state of Sao Paulo. We find that an increase at the total crimes registered reduces confidence on police. Such results are more effusively in some crimes like drug dealing and rape. Exploring heterogeneities in the results we find that black are more sensitive to crime rate changes even living in similar neighborhoods in what respect to security. Results also show that who has already had prior experience with the police is less sensitive independently of the quality of police job at the time.
\end{abstract}

Keywords: Trust in the Police, Institutions, Criminality

\footnotetext{
${ }^{1}$ Center for Applied Legal Research. University of Sao Paulo.

${ }^{2}$ Center for Applied Legal Research. University of Sao Paulo (USP).

${ }^{3}$ Center for Applied Legal Research.

${ }^{4}$ Center for Applied Legal Research. São Paulo School of Economics - FGV.
} 


\section{Introduction}

The police is the state's first-line representative with respect to citizens. Hence its legitimacy amongst the latter is of paramount importance in maintaining social order. Determining what determines citizens' motives for trusting or not trusting the police constitutes, therefore, a highly relevant subject in terms of public policy. Potential risk factors for violence encompass conditions at various levels: individual, family, community, and society at large.

In general, emerging countries are poorer than developed countries and also have large populations of young men. Leaving all other factors aside, these features are associated with higher crime rates than those found in developed countries. Becker (1968) models the objective function of an offender having as inputs the return on committing the crime, the probability of receiving punishment, and the severity of the punishment itself. It is therefore important to measure the determinants of trust in police, since this could create a variety of incentives related to obeying the law.

A brief review of the literature on the subject reveals an empirical ambiguity regarding the causal relationship between concern about local crime and trust in police. Some studies adopt the level of trust in the police as the dependent variable, and are therefore subject to influences by local conditions such as crime rates. These studies argue that people hold police accountable for local crime, disorder, and lack of public safety (Reisig and Parks, 2000; Sampson and Jeglum-Bartusch, 1998). Other studies have examined crime rates as being determined, in part, by the extent of trust in the police (Povey, 2001; Reisig and Parks, 2004).

Our paper reverses causation, treating crime rates as a dependent variable and examing its impact on trust in the police. This causal ordering is present in several studies that conclude that where residents perceive higher crime rates, and where fear of crime is high, trust in the police is consequently lower. Communities whose residents believe, for instance, that their neighborhood is afflicted by drug dealing and gangs are less likely to trust the police (Jesilow, Meyer, and Namazzi, 1995).

Although public assessments of police have become the chief concern of a substantial amount of research, only a small set of studies has analyzed public trust in development countries. This study analyzes the relationship between concern about local crime and trust in the police in the Brazilian setting and thus seeks to contribute to the literature by examining whether regions that have higher crime rates have lower trust in the police.

The application of this analysis to the state of São Paulo offers other possibilities. Poverty in Brazilian metropolitan regions like São Paulo is rampant and has a multidimensional character in terms of public services, access to education, and income. Additionally, Brazil has a peculiar public security system in that its police forces are subdivided two classes: civil and military. The military police is more overt -- it carries out most on-the-ground operations -- whereas the civil police plays a more investigative role. This model tends to produce different perceptions by the population. Another of our contributions is to separately analyze different types of crimes, such as property-violating crimes, life-threatening crimes, drug dealing, and sexual offenses, each of which affects the population's trust in the police in a distinct manner. This study is therefore relevant to establishing some explanations for public perceptions about the police. Understanding the population's views on the trustworthiness of the police may help the police managers to improve public participation in crime prevention programs as well as broader police-community relations in Brazil. 
We use data collected by the Trust in Justice Survey conducted by São Paulo Law School of Getulio Vargas Foundation along 2013 and 2014. To address the problem of simultaneity bias due to the correlation between trust on police and crime rates, we apply a Two Least Square approach using as the instrumental variable the distance of each respondent to their closest police station.

Our results show that an increase of $1 \%$ on total crime per capita rate reduces trust on the police by about 450 basis points. This impact is even more dramatic in the special cases of rape and drug dealing. It is only significant, however, for black persons and for people who have never had previous experience with the police.

This article is organized as follows: Section 2 discusses the empirical literature related to crime and trust on police and shows the institutional background of police work in Brazil; Section 3 describes our database; Section 4 describes our methodology and the identification strategy; Section 5 displays our main results; Section 6 opens a discussion about some subsamples of interest; and finally Section 7 concludes the discussion.

\section{Literature Review}

\subsection{Does Concern about Crime Affect Trust in the Police?}

In this study, we analyze the impact of crime rates on trust in the police. Citizen evaluations of the police are a critical issue for police administrators during the information technology era, as locality-based crime prevention and fighting strategies become integral parts of a new policing model mainly driven by data and technology (Rosenbaum, 2007). Jesilow, Meyer and Namazzi (1995) show that communities whose residents believe, for instance, that their neighborhood is afflicted by drug dealing and gangs are more likely to be critical of the police than residents of other areas. The same is true for those who believe that crime is a serious problem in their neighborhood (Weitzer and Tuch, 2004a, 2004b; Weitzer, Tuch and Skogan, 2008) and for those who report that a violent crime occurred in their neighborhood in the past year (Weitzer and Tuch, 2002).

Our study is very similar in that it has adopted the accountability model. We embed survey respondents in their neighborhood context, which includes crime rates. Sampson and JeglumBartusch (1998) and Reisig and Parks (2000) both show that variations in neighborhood homicide rates are related to differences in assessments of the police. Their results are robust even when controlling for important neighborhood characteristics such as poverty and also for individual factors like race and previous experience with police. In this study our independent variables are different: we use life-threatening crimes, property-violation crimes, drug traffic and sexual offenses. The homicide rate, for example, is included in the life-threatening crime category. The idea is to analyze the difference between these variables in terms of their importance for trust in the police.

Sampson and Jeglum-Bartusch (1998) show that cynicism about the law and dissatisfaction with the police are a routine part of life in places that have high crime rates. People living in such areas are rooted in experiential differences associated with their neighborhood context. There is a theoretical school that consists of variations on the claim that people hold the police directly or indirectly responsible for neighborhood conditions. According to this approach, social conditions, including fear and helplessness, are important variables in explaining the trust or the distrust in the police. Consistent with this view, Xu, Fiedler and Flaming (2005) conclude that fear undermines satisfaction with police. From their standpoint, fearful people, who 
disproportionately live in high crime, disorderly, low-quality-of-life neighborhoods, believe their neigborhoods are unsafe because the police are unable or unwilling to help them.

High levels of social disorder signal to residents that law enforcement has lost its grip and that police protection is not to be trusted (Ren; Cao; Lovrich; Gaffney, 2005). Reisig and Parks (2000) and Velez (2001) show that residents of higher crime areas are more likely to report that officers perform poorly in maintaining order and fighting crime, that the police treat crime victims unsatisfactorily, and that the police are unresponsive to local issues.

Likewise, our study analyzes whether the public's perception of trust in the police changes when the crime rates change. There is the problem of a potential endogeneity between trust in the police and crime rates. Simultaneity issues are also likely to be present because people who have lower levels of trust in the police may disobey the law more often than other people. Respondents under such conditions may be naturally averse to the police. To put it another way, respondents whose neighborhoods are afflicted by drug dealing and gangs are more likely to distrust the police. We will treat this problem via an instrumental variable approach, to be presented and discussed in the next section.

\subsection{Institutional Background}

There are three police jurisdictions in Brazil: Federal, Civil and Military. The Federal Police is a judicial force charged with investigating all crimes that may interest the federal government. Their responsibilities are mainly investigative, namely: illegal international drugs and arms trade, terrorism, human smuggling, and any other crimes directed against the federal government or federal officers; their role is analogous to that of the US Federal Bureau of Investigation. Apart from typical criminal investigation works, the Federal Police Department also has many administrative police tasks, acting in particular as the chief Brazilian immigration authority. It additionally oversees the National Arms Control System (SINARM) and represents the National Central Authority as the liaison between Brazil and Interpol.

The Civil Police is the investigative state-level police force. Each of the 26 Brazilian states has its own Civil Police department, as does the Distrito Federal. Its role is to carry out detective work, forensics, and criminal investigation; it acts as a state bureau of investigation. Its main responsibilities are criminal investigation, vehicle registrations, support to judicial system, and issuance of the national identification card and of driver licenses. The Military Police also is subdivided by states. Deployed solely to act as a deterrent against criminal acts, they do not conduct criminal investigations. Their main responsibilities are uniformed patrol and crime prevention work, was well as civilian emergencies, which are dealt with by the Military Fire Fighters. The state Military Police Forces evolved from the former State Public Forces, and were originally inspired by the U.S. National Guards as actual Army Units designed for territorial defense. The Military Police are charged with investigating their own members' criminal misdeeds in cases subject both to the Civilian or to the Military Criminal Courts.

\section{Data}

Our database covers the quarterly Trust in Justice Survey conducted along 2013 and 2014 by the Getulio Vargas Foundation. These surveys were obtained via telephone calls over a period of twenty-one months. The population of the survey is constituted by persons who live in São Paulo state. Each respondent is an individual who represents a selected household, is of any gender and is over 18 years old. Our sample consists of 721 respondents in 2013 and 284 respondents in 2014. 
The question on trust in the police admits four response categories: $1=$ not at all confident, $2=$ not very confident, $3=$ fairly confident, and $4=$ very confident. The trust in the police variable is a dummy which takes value one when the response is very confident or fairly confident, and zero otherwise. We created a dummy variable that takes value one when respondent $i$ responds 3 or 4 , and zero otherwise.

We use five per capita crime-related variables, namely total crimes, life-threatening crimes, property-violation crimes, drug trafficking, and sexual offenses. Life-threatening crimes include homicide, robbery, kidnapping, and physical aggression. Property-violation crimes include robbery and theft. For each category, we have the per month number of crimes reported by police departments in the state of São Paulo from 2013 to 2014.

Our data on crime numbers come from the São Paulo Public Security Secretary (Secretaria de Segurança Pública do Estado de São Paulo) and only reflect reported crimes and victim information such as intentional homicide, rapes, drug trafficking, and armed robbery. Victim statistics are probably the most reliable source for violence-related data in São Paulo, because the São Paulo state law enforcement agencies compile of statistics for these types of crime. The police departments are heterogeneous in terms of size. Because of this, we constructed the per capita crimes variables using populations from sector censuses of the police stations in São Paulo.

Table 1 describes the main characteristics of per capita crime variables, our trust in police variables, and distance to police stations. As can be seen, $32 \%$ of respondents declare that they trust the police, and the average number of per capita total registered crimes is 0.37 . The most common type of crime are property-violation crimes, with a rate of 0.297 .

Table 1 -Descriptive Statistics for Trust and Crime Variables

\begin{tabular}{lc|cc|cc|ccc}
\hline & & \multicolumn{2}{c}{$\begin{array}{c}\text { Previous Experience } \\
\text { with the Police }\end{array}$} & $\begin{array}{c}\text { Previous Experience with } \\
\text { Police high rated }\end{array}$ & \multicolumn{2}{c}{ Race } \\
\hline & Full Sample & Yes & No & Yes & No & Blacks & Non-Blacks \\
\hline \multirow{2}{*}{ Trust in the Police } & $\mathbf{0 . 3 2 0}$ & $\mathbf{0 . 3 1 5}$ & $\mathbf{0 . 3 2 4}$ & $\mathbf{0 . 3 3 6}$ & $\mathbf{0 . 2 5 2}$ & $\mathbf{0 . 2 3 5}$ & $\mathbf{0 . 3 8 3}$ \\
& $(0.467)$ & $(0.465)$ & $(0.468)$ & $(0.473)$ & $(0.435)$ & $(0.425)$ & $(0.486)$ \\
\hline \multicolumn{7}{c|}{ Per capita Crime incidence } \\
\hline \multirow{2}{*}{ All types of Crimes } & $\mathbf{0 . 3 7 9}$ & $\mathbf{0 . 3 6 5}$ & $\mathbf{0 . 3 8 9}$ & $\mathbf{0 . 3 7 2}$ & $\mathbf{0 . 3 7 7}$ & $\mathbf{0 . 3 8 6}$ & $\mathbf{0 . 3 7 4}$ \\
& $(0.726)$ & $(0.758)$ & $(0.703)$ & $(0.94)$ & $(0.352)$ & $(0.353)$ & $(0.907)$ \\
Property-Violating & $\mathbf{0 . 2 9 7}$ & $\mathbf{0 . 2 8 6}$ & $\mathbf{0 . 3 0 6}$ & $\mathbf{0 . 2 9 2}$ & $\mathbf{0 . 2 9 8}$ & $\mathbf{0 . 3 0 3}$ & $\mathbf{0 . 2 9 3}$ \\
Crimes & $(0.628)$ & $(0.654)$ & $(0.608)$ & $(0.812)$ & $(0.299)$ & $(0.298)$ & $(0.786)$ \\
Life-threatening & $\mathbf{0 . 0 7 0}$ & $\mathbf{0 . 0 6 8}$ & $\mathbf{0 . 0 7 1}$ & $\mathbf{0 . 0 6 8}$ & $\mathbf{0 . 0 6 8}$ & $\mathbf{0 . 0 7 1}$ & $\mathbf{0 . 0 7 0}$ \\
Crimes & $(0.09)$ & $(0.094)$ & $(0.088)$ & $(0.111)$ & $(0.06)$ & $(0.059)$ & $(0.108)$ \\
Drug Traffic & $\mathbf{0 . 0 0 3}$ & $\mathbf{0 . 0 0 3}$ & $\mathbf{0 . 0 0 3}$ & $\mathbf{0 . 0 0 3}$ & $\mathbf{0 . 0 0 3}$ & $\mathbf{0 . 0 0 3}$ & $\mathbf{0 . 0 0 3}$ \\
& $(0.005)$ & $(0.005)$ & $(0.005)$ & $(0.006)$ & $(0.003)$ & $(0.004)$ & $(0.006)$ \\
Sexual Offenses & $\mathbf{0 . 0 0 9}$ & $\mathbf{0 . 0 0 9}$ & $\mathbf{0 . 0 0 9}$ & $\mathbf{0 . 0 0 9}$ & $\mathbf{0 . 0 0 8}$ & $\mathbf{0 . 0 0 9}$ & $\mathbf{0 . 0 0 9}$ \\
& $(0.017)$ & $(0.018)$ & $(0.016)$ & $(0.021)$ & $(0.012)$ & $(0.012)$ & $(0.02)$ \\
\hline Total Respondents & 1005 & 422 & 583 & 253 & 169 & 425 & 580 \\
\hline
\end{tabular}

Notes: 1) Data on trust on police come from the Brazilian Confidence in Justice Survey coordinated by Getulio Vargas Foundation, with 1005 respondents. 2) The upper lines on table show the sample average of each variable. The lower lines report the standard deviation and the bottom line shows the number of observations. 3) 'Per capita crime incidence' means that we divided the number of crimes registered at the police departments where each individual lives by the 2010 total population of her Sector Census.

Table 2 details the variables that control for individual heterogeneity. 
Table 2 - Definitions for the Principal Variables

\begin{tabular}{|c|c|}
\hline Woman & $\begin{array}{l}\text { Dummy variable that takes value one when the respondent is female, and zero } \\
\text { otherwise; }\end{array}$ \\
\hline Black & $\begin{array}{l}\text { Dummy variable that takes value one when the respondent is black, and zero } \\
\text { otherwise; }\end{array}$ \\
\hline $\begin{array}{l}0 \text { to } 1 \text { Minimum } \\
\text { Wages }\end{array}$ & $\begin{array}{l}\text { Dummy variable that takes value one when the respondent's salary is from } 0 \text { to } \\
1 \text { minimum wages, and zero otherwise; }\end{array}$ \\
\hline $\begin{array}{l}1 \text { to } 4 \text { Minimum } \\
\text { Wages }\end{array}$ & $\begin{array}{l}\text { Dummy variable that takes value one when the respondent's salary is from } 1 \text { to } \\
4 \text { minimum wages, and zero otherwise; }\end{array}$ \\
\hline $\begin{array}{l}4 \text { to } 8 \text { Minimum } \\
\text { Wages }\end{array}$ & $\begin{array}{l}\text { Dummy variable that takes value one when the respondent's salary is from } 4 \text { to } \\
8 \text { minimum wages, and zero otherwise; }\end{array}$ \\
\hline 8 Minimum Wages & $\begin{array}{l}\text { Dummy variable that takes value one when the respondent's salary is higher } \\
\text { than } 8 \text { minimum wages, and zero otherwise; }\end{array}$ \\
\hline $\begin{array}{l}\text { Formal Contract } \\
\text { Work }\end{array}$ & $\begin{array}{l}\text { Dummy variable that takes value one when the respondent has a formal job, and } \\
\text { zero otherwise; }\end{array}$ \\
\hline Occupied & $\begin{array}{l}\text { Dummy variable that takes value one when the respondent has a formal or } \\
\text { informal job, and zero otherwise; }\end{array}$ \\
\hline$\overline{\text { Age }}$ & is the respondent's age in years; \\
\hline Schooling Years & is the respondent's education in years; \\
\hline Married & $\begin{array}{l}\text { Dummy variable that takes value one when the respondent is married, and zero } \\
\text { otherwise; }\end{array}$ \\
\hline $\begin{array}{l}\text { Had Previous } \\
\text { Experience with the } \\
\text { Police }\end{array}$ & $\begin{array}{l}\text { Dummy variable that takes value one when the respondent called the police for } \\
\text { help, and zero otherwise; }\end{array}$ \\
\hline $\begin{array}{l}\text { Positive View of } \\
\text { Police Performance }\end{array}$ & $\begin{array}{l}\text { Dummy variable that takes value one when the respondent that called the police } \\
\text { for help was satisfied with the service provided, and zero otherwise; }\end{array}$ \\
\hline
\end{tabular}

Table 3 displays descriptive statistics for covariates. It shows that $42 \%$ of respondents have had previous experience with the police and that $25 \%$ among these think that the police had performed well. Of those who have had previous experience with the police, $54 \%$ are female and $48 \%$ are black. As for women who have had previous experience with the police, $53 \%$ of them stated that the police had done a good job. However, only $45 \%$ of black persons who have had previous experience with the police stated that the police had performed well.

Our sample is similar to overall São Paulo demographic data in terms of gender and race. In our sample, $51 \%$ of respondents are female and $7 \%$ are black. According to the 2010 census the black share of the São Paulo population is $6 \%$ and the female share of the population is $52 \%$. Households with monthly per capita income between 0 and 1 minimum wages account for $43 \%$ of households. For the São Paulo population as a whole this share is $42 \%$. Households with monthly per capita income between 1 and 4 minimum wages account for $40 \%$ of population. In our sample the corresponding share is $38 \%$. 
Table 3 - Descriptive Statistics for the Covariates

\begin{tabular}{|c|c|c|c|c|c|c|c|}
\hline & \multicolumn{2}{|c|}{$\begin{array}{l}\text { Previous Experience } \\
\text { with the Police }\end{array}$} & \multicolumn{2}{|c|}{$\begin{array}{c}\text { Previous Experience } \\
\text { with Police high rated }\end{array}$} & \multicolumn{2}{|c|}{ Race } \\
\hline & & Yes & No & Yes & No & Blacks & Non-Blacks \\
\hline Female & $\begin{array}{c}\mathbf{0 . 5 1 5} \\
(0.5)\end{array}$ & $\begin{array}{c}\mathbf{0 . 5 4 3} \\
(0.499)\end{array}$ & $\begin{array}{c}\mathbf{0 . 4 9 6} \\
(0.5)\end{array}$ & $\begin{array}{c}\mathbf{0 . 5 3 8} \\
(0.5)\end{array}$ & $\begin{array}{c}\mathbf{0 . 5 2 3} \\
(0.501)\end{array}$ & $\begin{array}{c}\mathbf{0 . 4 5 6} \\
(0.499)\end{array}$ & $\begin{array}{c}\mathbf{0 . 5 5 9} \\
(0.497)\end{array}$ \\
\hline Black & $\begin{array}{c}\mathbf{0 . 0 7 5} \\
(0.132)\end{array}$ & $\begin{array}{c}\mathbf{0 . 4 8 7} \\
(0.491)\end{array}$ & $\begin{array}{c}\mathbf{0 . 5 2 1} \\
(0.496)\end{array}$ & $\begin{array}{c}\mathbf{0 . 4 5 8} \\
(0.488)\end{array}$ & $\begin{array}{c}\mathbf{0 . 5 6 2} \\
(0.545)\end{array}$ & & \\
\hline 0 to 1 Minimum Wages & $\begin{array}{c}\mathbf{0 . 4 3 1} \\
(0.213)\end{array}$ & $\begin{array}{c}\mathbf{0 . 4 1 4} \\
(0.166)\end{array}$ & $\begin{array}{c}\mathbf{0 . 4 5 1} \\
(0.241)\end{array}$ & $\begin{array}{c}\mathbf{0 . 4 2 1} \\
(0.186)\end{array}$ & $\begin{array}{l}\mathbf{0 . 4 0 1} \\
(0.14)\end{array}$ & $\begin{array}{l}\mathbf{0 . 0 6 1} \\
(0.24)\end{array}$ & $\begin{array}{c}\mathbf{0 . 0 3 8} \\
(0.191)\end{array}$ \\
\hline 1 to 4 Minimum Wages & $\begin{array}{c}\mathbf{0 . 3 8 2} \\
(0.5)\end{array}$ & $\begin{array}{c}\mathbf{0 . 4 3 6} \\
(0.496)\end{array}$ & $\begin{array}{c}\mathbf{0 . 5 0 1} \\
(0.5)\end{array}$ & $\begin{array}{c}\mathbf{0 . 5 0 2} \\
(0.501)\end{array}$ & $\begin{array}{c}\mathbf{0 . 3 7 1} \\
(0.485)\end{array}$ & $\begin{array}{c}\mathbf{0 . 5 0 6} \\
(0.501)\end{array}$ & $\begin{array}{c}\mathbf{0 . 4 5 0} \\
(0.498)\end{array}$ \\
\hline 4 to 8 Minimum Wages & $\begin{array}{c}\mathbf{0 . 1 0 1} \\
(0.462)\end{array}$ & $\begin{array}{l}\mathbf{0 . 3 3 9} \\
(0.474)\end{array}$ & $\begin{array}{l}\mathbf{0 . 2 8 5} \\
(0.452)\end{array}$ & $\begin{array}{c}\mathbf{0 . 3 2 4} \\
(0.469)\end{array}$ & $\begin{array}{c}\mathbf{0 . 4 0 4} \\
(0.492)\end{array}$ & $\begin{array}{c}\mathbf{0 . 2 9 6} \\
(0.457)\end{array}$ & $\begin{array}{c}\mathbf{0 . 3 1 6} \\
(0.465)\end{array}$ \\
\hline $\begin{array}{l}8 \text { or more Minimum } \\
\text { Wages }\end{array}$ & $\begin{array}{c}\mathbf{0 . 0 1 6} \\
(0.331)\end{array}$ & $\begin{array}{c}\mathbf{0 . 1 5 6} \\
(0.364)\end{array}$ & $\begin{array}{c}\mathbf{0 . 1 0 3} \\
(0.304)\end{array}$ & $\begin{array}{c}\mathbf{0 . 1 3 8} \\
(0.346)\end{array}$ & $\begin{array}{c}\mathbf{0 . 2 0 5} \\
(0.405)\end{array}$ & $\begin{array}{c}\mathbf{0 . 0 9 6} \\
(0.296)\end{array}$ & $\begin{array}{c}\mathbf{0 . 1 4 7} \\
(0.354)\end{array}$ \\
\hline Formal Contract Work & $\begin{array}{c}\mathbf{0 . 3 2 2} \\
(0.468)\end{array}$ & $\begin{array}{c}\mathbf{0 . 3 5 1} \\
(0.478)\end{array}$ & $\begin{array}{c}\mathbf{0 . 3 0 2} \\
(0.459)\end{array}$ & $\begin{array}{c}\mathbf{0 . 3 6 4} \\
(0.482)\end{array}$ & $\begin{array}{c}\mathbf{0 . 3 6 4} \\
(0.483)\end{array}$ & $\begin{array}{c}\mathbf{0 . 3 4 1} \\
(0.475)\end{array}$ & $\begin{array}{c}\mathbf{0 . 3 0 9} \\
(0.462)\end{array}$ \\
\hline Occupied & $\begin{array}{c}\mathbf{0 . 7 1 3} \\
(0.452)\end{array}$ & $\begin{array}{l}\mathbf{0 . 7 7 3} \\
(0.42)\end{array}$ & $\begin{array}{l}\mathbf{0 . 6 7 1} \\
(0.47)\end{array}$ & $\begin{array}{l}\mathbf{0 . 7 3 9} \\
(0.44)\end{array}$ & $\begin{array}{c}\mathbf{0 . 8 2 8} \\
(0.379)\end{array}$ & $\begin{array}{c}\mathbf{0 . 7 3 2} \\
(0.444)\end{array}$ & $\begin{array}{c}\mathbf{0 . 7 0 0} \\
(0.459)\end{array}$ \\
\hline Age & $\begin{array}{c}\mathbf{4 1 . 7 5 5} \\
(15.228)\end{array}$ & $\begin{array}{c}\mathbf{3 9 . 9 6 9} \\
(13.882)\end{array}$ & $\begin{array}{l}\mathbf{4 3 . 0 4 8} \\
(16.02)\end{array}$ & $\begin{array}{c}\mathbf{4 0 . 8 2 6} \\
(14.486)\end{array}$ & $\begin{array}{r}\mathbf{3 8 . 4 7 0} \\
(12.923)\end{array}$ & $\begin{array}{c}\mathbf{3 8 . 6 7 1} \\
(14.553)\end{array}$ & $\begin{array}{c}\mathbf{4 4 . 0 1 6} \\
(15.327)\end{array}$ \\
\hline Schooling Years & $\begin{array}{c}9.746 \\
(3.735)\end{array}$ & $\begin{array}{l}\mathbf{1 0 . 5 9 0} \\
(3.394)\end{array}$ & $\begin{array}{l}\mathbf{9 . 1 3 6} \\
(3.852)\end{array}$ & $\begin{array}{l}\mathbf{1 0 . 2 7 3} \\
(3.515)\end{array}$ & $\begin{array}{l}\mathbf{1 1 . 1 8 5} \\
(3.153)\end{array}$ & $\begin{array}{c}\mathbf{9 . 1 4 8} \\
(3.452)\end{array}$ & $\begin{array}{l}\mathbf{1 0 . 1 8 4} \\
(3.873)\end{array}$ \\
\hline Married & $\begin{array}{c}\mathbf{0 . 5 5 0} \\
(0.498)\end{array}$ & $\begin{array}{c}\mathbf{0 . 5 3 6} \\
(0.499)\end{array}$ & $\begin{array}{l}\mathbf{0 . 5 6 1} \\
(0.497)\end{array}$ & $\begin{array}{l}\mathbf{0 . 5 1 0} \\
(0.501)\end{array}$ & $\begin{array}{c}\mathbf{0 . 5 5 0} \\
(0.499)\end{array}$ & $\begin{array}{c}\mathbf{0 . 5 0 6} \\
(0.501)\end{array}$ & $\begin{array}{c}\mathbf{0 . 5 8 3} \\
(0.494)\end{array}$ \\
\hline Capital & $\begin{array}{c}\mathbf{0 . 2 6 0} \\
(0.439)\end{array}$ & $\begin{array}{c}\mathbf{0 . 2 3 0} \\
(0.421)\end{array}$ & $\begin{array}{l}\mathbf{0 . 2 8 1} \\
(0.45)\end{array}$ & $\begin{array}{l}\mathbf{0 . 2 0 6} \\
(0.405)\end{array}$ & $\begin{array}{c}\mathbf{0 . 2 9 8} \\
(0.459)\end{array}$ & $\begin{array}{c}\mathbf{0 . 3 4 4} \\
(0.475)\end{array}$ & $\begin{array}{c}\mathbf{0 . 1 9 8} \\
(0.399)\end{array}$ \\
\hline $\begin{array}{l}\text { Had Previous Experience } \\
\text { with the Police }\end{array}$ & $\begin{array}{c}\mathbf{0 . 4 2 0} \\
(0.494)\end{array}$ & & & & & $\begin{array}{r}\mathbf{0 . 4 0 0} \\
(0.49)\end{array}$ & $\begin{array}{c}\mathbf{0 . 4 3 4} \\
(0.496)\end{array}$ \\
\hline $\begin{array}{l}\text { Positive View of Police } \\
\text { Experience }\end{array}$ & $\begin{array}{r}\mathbf{0 . 2 5 2} \\
(0.434)\end{array}$ & $\begin{array}{r}\mathbf{0 . 6 0 0} \\
(0.491)\end{array}$ & $\begin{array}{l}\mathbf{0 . 4 0 0} \\
(0.475)\end{array}$ & & & $\begin{array}{c}\mathbf{0 . 2 3 1} \\
(0.422) \\
\end{array}$ & $\begin{array}{r}\mathbf{0 . 2 6 7} \\
(0.443)\end{array}$ \\
\hline
\end{tabular}

Notes: 1) Data about trust on the police come from the Brazilian Confidence in Justice Survey coordinated by Getulio Vargas Foundation, with 1005 respondents. 2) The upper lines on the table are the sample averages for each variable. The bottom lines reports the standard deviation. 3) Wages are measured in terms of the 2014 Minimum Wage, which corresponds to 306 dollars.

\section{Empirical Approach}

\subsection{Identification Strategy}

There is a well-known debate about the roles of geography versus institutions in explaining the long-term development of countries. For example, Acemoglu, Johnson, and Robinson (2001) argue that geographic conditions, particularly high disease burdens, affected European settlement patterns, which in turn led to extractive institutions in non-settler economies and development-friendly institutions in settler economies. It is nevertheless worthwhile to consider the institutions and the provision of public services at the micro level within a country, as this allows one to examine in detail what kind of institutions matter and moreover how they are viewed by society in terms of trust. 
Geography can have an indirect effect on the levels of trust in institutions, including in the police department. Rodrik, Subramanian, and Trebbi (2002) show that the distance and the integration between geographic regions explain the emergence of some regional elites as well as the quality of some institutions. According to them regions that are distant from major economic centers tend to exhibit lower rates of economic and social development. They also show that geographically distant regions exhibit the greatest social inequalities and are the most socially vulnerable. Glaeser (2005) provides evidence that when inequality rises the returns to crime increase for the poor, because (1) victims become richer, and (2) the opportunity costs of crime decrease as the poor become poorer. He also shows that the rich tend to desire a legal system focused on protecting property while the poor tend to be more concerned with preventing interpersonal violence. These divergent goals diminish the societal willingness to invest in a mutually beneficial legal system. On the whole, poorer areas tend to have fewer public services when compared to less poor areas. Although this study does not analyze the effects of economic inequality, it does use the distance between the respondent's home and the nearest police department as an instrument for crime rate.

Some studies show that trust in the police is lower in places where residents perceive higher crime rates. Communities whose residents believe, for instance, that their neighborhood is afflicted by drug dealing and gangs are more likely than residents of other areas to be critical of the police (Jesilow; Meyer; and Namazzi, 1995). The same is true for those who believe that crime is a serious problem in their neighborhood (Weitzer and Tuch, 2004a, 2004b; Weitzer; Tuch; and Skogan, 2008) and for those who report that a violent crime occurred in their neighborhood in the past year (Weitzer and Tuch, 2002).

We use the euclidean distance from a respondent's home to the nearest police department as the instrumental variable for crime rates. In order to find a causal effect we must have that the only way the distance of an individual to the police station can affect trust in police is via the channel of affecting his or her neighborhood's crime rate.

Our argument is that the distance between the respondent's home and the nearest police department does not affect directly the trust in police, because the choice of where to live is not directly associated with the level of trust that people have in police, but it is strongly related to household income. Thus, our exogeneity hypothesis is that the distance between the respondent's home and the nearest police department affects the trust in police only through crime rate.

One specificity found in the instrumental variable approach is that our results must be interpreted as local estimators (Angrist and Pischke, 2009). This means that, under the hypotheses described above, we are estimating the causal effect of crime rates changes on trust in police only for the subsample of the population whose perceived crime rates in their neighborhood are somehow affected by distance to the police station. Otherwise our estimators no longer would not infer a causal relationship.

\subsection{Econometric Specification}

In this study we test the hypothesis that trust in the police is affected by changes in crime rates. Assuming that different types of crimes can have distinct relationships to the populations' perception of safety, we run regressions for four kinds of crime life-threatening crimes, property-violation crimes, drug trafficking, and sexual offenses.

Ideally, our experiment would involve observing and comparing the same individual's trust in police in two distinct situations: one where he or she would be exposed to average crime rates, 
and another where he or she would have contact with a slightly higher crime rate. Given the impossibility of such a task (Holland, 1986), even if we ran an OLS regression of trust in police on crime rate we would not obtain an unbiased estimator due to the classic problem of 'bias of simultaneity' (Wooldridge, 2010). This problem consists of the fact that at the same time that changes in crime rates affects trust in the police, variations in trust in the police can change crime rates.

In order to understand the second relationship, assume that in a region where people trust less the police they are more likely to commit crimes. As OLS incurs in biased estimators, we ran Two Stage Least Square Regression (2SLS) as defined in Hayashi (2000). Our idea here was to find an instrumental variable that is at the same time correlated to crime rates but not correlated to the deviation term in the regression. We adopted the distance of the individual to the closest police station as the instrumental variable for crime rates. The estimation can be described in two stages:

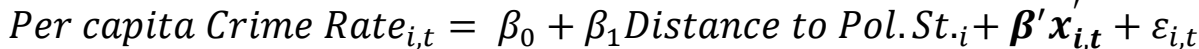

$$
\begin{aligned}
& \text { Confidence in the Police }_{i, t}=\pi_{0}+\pi_{1} \text { Per capıta } \overline{\text { Crlmes }} \text { Rates }_{i, t}+\boldsymbol{\pi}^{\prime} \boldsymbol{x}_{\boldsymbol{i}, \boldsymbol{t}}^{\prime}+\sigma_{i, t}
\end{aligned}
$$

where equation (1) represents the first stage and equation 2 the second stage, $\pi_{1}$ is the coefficient that measures the relationship between trust in police and crime rate that we want to test, and $\boldsymbol{x}_{\boldsymbol{i}, \boldsymbol{t}}$ is a vector of covariates that we use as control variables on regressions. The control variables are income dummy, gender dummy, race dummy, marital status dummy, schooling years, formal contract status dummy, employment dummy, and quarter dummies.

\section{Empirical Results}

Table 4 presents Two Stage Least Square results as described by equations (1) and (2). We note that for all kinds of crimes an increase in crime rates is negatively related to trust in the police. For instance, if the total per capita crime increases about $1 \%$ then trust in the police decreases by 4.5 percentage points.

The effects of property-violation crime rate changes are quite similar to those of the total crime rate because, as pointed out on Erro! Fonte de referência não encontrada., most of total registered crimes relate to private property. In the same way, drug dealing and sexual offenses have a much greater impact on police trust because their statistical incidence is smaller. Increases in drug dealing and sexual offenses draw much more attention from public opinion than private property crimes.

Our evidence corroborates the existing literature that uses surveyed data to identify variables associated with citizen satisfaction relative police. Reported concerns about public trust and trust in the police rely on the assumption that trust shapes public cooperation. Measures of public satisfaction with the police are also important because perceptions of the police affect citizen cooperation (Weitzer, 1999). This result suggests that government should have the police engage in trust-building activities in order to increase public approval of its services. 
Table 4 - 2SLS Regressions for Trust in the Police and Crime Rates Measures

\begin{tabular}{|c|c|c|c|c|c|}
\hline & $\begin{array}{c}\text { Total per } \\
\text { Capita } \\
\text { Crimes }\end{array}$ & $\begin{array}{c}\text { Per Capita } \\
\text { Private } \\
\text { Property } \\
\text { Crimes } \\
\end{array}$ & $\begin{array}{l}\text { Drug Traffic } \\
\text { Incidence }\end{array}$ & $\begin{array}{l}\text { Per Capita } \\
\text { Homicides }\end{array}$ & $\begin{array}{c}\text { Per capita } \\
\text { Rape } \\
\text { Incidence }\end{array}$ \\
\hline$\pi_{1}$ & $\begin{array}{c}-0.045 * \\
(-1.79) \\
\end{array}$ & $\begin{array}{c}-0.041 * \\
(-1.77) \\
\end{array}$ & $\begin{array}{c}-0.139 * \\
(-1.92) \\
\end{array}$ & $\begin{array}{c}-0.161 * \\
(-1.80) \\
\end{array}$ & $\begin{array}{c}-0.160 * \\
(-1.84) \\
\end{array}$ \\
\hline Woman & $\begin{array}{l}-0.052 \\
(-1.60)\end{array}$ & $\begin{array}{l}-0.057 \\
(-1.61)\end{array}$ & $\begin{array}{c}-0.065 * \\
(-1.81)\end{array}$ & $\begin{array}{l}-0.048 \\
(-1.54)\end{array}$ & $\begin{array}{c}-0.064 * \\
(-1.87)\end{array}$ \\
\hline Black & $\begin{array}{c}-0.131 * * * \\
(-4.39) \\
\end{array}$ & $\begin{array}{c}-0.134 * * * \\
(-4.20) \\
\end{array}$ & $\begin{array}{c}-0.115 * * * \\
(-3.51) \\
\end{array}$ & $\begin{array}{c}-0.130 * * * \\
(-4.10) \\
\end{array}$ & $\begin{array}{c}-0.119 * * * \\
(-3.53)\end{array}$ \\
\hline 0 to 1 Minimum Wages & $\begin{array}{l}-0.102 \\
(-1.27)\end{array}$ & $\begin{array}{l}-0.095 \\
(-1.15)\end{array}$ & $\begin{array}{l}-0.134 \\
(-1.62)\end{array}$ & $\begin{array}{l}-0.100 \\
(-1.21)\end{array}$ & $\begin{array}{l}-0.111 \\
(-1.32)\end{array}$ \\
\hline 1 to 4 Minimum Wages & $\begin{array}{c}-0.090 * \\
(-1.79)\end{array}$ & $\begin{array}{c}-0.090 * \\
(-1.86)\end{array}$ & $\begin{array}{c}-0.127 * * \\
(-2.39)\end{array}$ & $\begin{array}{c}-0.087 * \\
(-1.73)\end{array}$ & $\begin{array}{c}-0.084 * \\
(-1.77)\end{array}$ \\
\hline 4 to 8 Minimum Wages & $\begin{array}{c}-0.085 * \\
(-1.77) \\
\end{array}$ & $\begin{array}{l}-0.090 * \\
(-1.85) \\
\end{array}$ & $\begin{array}{c}-0.131 * * \\
(-2.50) \\
\end{array}$ & $\begin{array}{c}-0.081 * \\
(-1.65) \\
\end{array}$ & $\begin{array}{l}-0.079 \\
(-1.64) \\
\end{array}$ \\
\hline Schooling years & $\begin{array}{l}-0.006 \\
(-1.38)\end{array}$ & $\begin{array}{l}-0.007 \\
(-1.39)\end{array}$ & $\begin{array}{l}-0.008 \\
(-1.63)\end{array}$ & $\begin{array}{l}-0.006 \\
(-1.35)\end{array}$ & $\begin{array}{l}-0.008 \\
(-1.62)\end{array}$ \\
\hline Age & $\begin{array}{l}0.001 \\
(1.26)\end{array}$ & $\begin{array}{l}0.001 \\
(0.96)\end{array}$ & $\begin{array}{l}0.001 \\
(1.18)\end{array}$ & $\begin{array}{l}0.002 \\
(1.44)\end{array}$ & $\begin{array}{l}0.002 \\
(1.59)\end{array}$ \\
\hline Married & $\begin{array}{c}-0.068 * * \\
(-2.16)\end{array}$ & $\begin{array}{c}-0.066 * * \\
(-2.13)\end{array}$ & $\begin{array}{c}-0.060 * \\
(-1.92)\end{array}$ & $\begin{array}{c}-0.070 * * \\
(-2.24)\end{array}$ & $\begin{array}{c}-0.077 * * \\
(-2.45)\end{array}$ \\
\hline Formal contract work & $\begin{array}{l}0.014 \\
(0.41)\end{array}$ & $\begin{array}{l}0.008 \\
(0.24)\end{array}$ & $\begin{array}{l}0.023 \\
(0.66)\end{array}$ & $\begin{array}{l}0.014 \\
(0.40)\end{array}$ & $\begin{array}{l}0.027 \\
(0.77)\end{array}$ \\
\hline Occupied & $\begin{array}{l}-0.038 \\
(-0.94) \\
\end{array}$ & $\begin{array}{l}-0.037 \\
(-0.96) \\
\end{array}$ & $\begin{array}{l}-0.020 \\
(-0.49) \\
\end{array}$ & $\begin{array}{l}-0.034 \\
(-0.85) \\
\end{array}$ & $\begin{array}{l}-0.012 \\
(-0.29) \\
\end{array}$ \\
\hline $\begin{array}{l}\text { Observations } \\
\text { R-squared } \\
\end{array}$ & $\begin{array}{c}956 \\
0.0369 \\
\end{array}$ & $\begin{array}{c}956 \\
0.0369 \\
\end{array}$ & $\begin{array}{c}956 \\
0.0369 \\
\end{array}$ & $\begin{array}{c}956 \\
0.0369 \\
\end{array}$ & $\begin{array}{c}956 \\
0.0369 \\
\end{array}$ \\
\hline \multicolumn{6}{|c|}{ First Stage Estimation } \\
\hline Distance & $\begin{array}{c}-0.228 * * * \\
(-15.78) \\
\end{array}$ & $\begin{array}{c}-0.251 * * * \\
(-13.46) \\
\end{array}$ & $\begin{array}{c}-0.074 * * * \\
(-5.98) \\
\end{array}$ & $\begin{array}{c}-0.167 * * * \\
(-11.77) \\
\end{array}$ & $\begin{array}{c}-0.063 * * * \\
(-8.59) \\
\end{array}$ \\
\hline F - Statistic & $31.63 * * *$ & $26.16 * * *$ & $11.15 * *$ & $15.74 * * *$ & $12.72 * * *$ \\
\hline
\end{tabular}

\section{Discussion}

\subsection{Does Past Experience with the Police Have any Impact on Respondent Opinion?}

Section 4.6 has shown a negative relationship between crime incidence and trust in the police. Important questions, however, arise regarding to what degree crime incidence can be attributed to police work, as well as what are the consequences of adding other variables, such as poverty, income inequality, size of young population, or law enforcement.

It is reasonable to assume that a large share of population has never personally demanded police service. This probably affects the population's perception of police responsiveness to crime. Table 5 displays 2SLS estimates for the crime incidence effect on trust in police for subgroups of people with (PANEL A) and without (PANEL B) past experience with the police. As can be seen in the first stage report, in all cases the instruments are quite strong and there are slightly fewer people who have used police services. The results of the second stage are quite interesting in that they show that, for the subgroup with prior experience with the police, rising crime 
incidence does not affect trust in the police. In contrast, people lacking past experience with police work do not have a statistically significant impact.

Yet more interesting, we have found that their coefficients are higher than those estimated for the entire sample. For those who have had not have a prior experience with the police, an increase in total crime of $1 \%$ decreases total crimes by 5.3 percentage points. This result suggests that people update their information set about police work once they have had a closer experience with police work. Apparently they tone down the responsibility ascribed to the police for crimes once they become more familiar with the institution's work.

Table 5 - 2SLS Regressions for Trust in the Police using Subsamples of People who Have Previous Experience with the Police

\begin{tabular}{ccccc}
\hline Total \\
Crimes
\end{tabular}$\quad$ Private Property Crimes $\begin{gathered}\text { Drug traffic } \\
\text { Incidence }\end{gathered}$ Life Crimes $\begin{gathered}\text { Rape } \\
\text { Incidence }\end{gathered}$

\begin{tabular}{lccccc}
\hline \hline PANEL A: Using people who have had previous experience with the police & & \\
\hline \hline Had Previous Experience & -0.027 & -0.025 & -0.098 & -0.038 & -0.140 \\
& $(-0.62)$ & $(-0.64)$ & $(-0.63)$ & $(-0.64)$ & $(-0.65)$ \\
\hline Observations & 407 & 407 & 407 & 407 & 407 \\
R-squared & 0.074 & 0.074 & 0.074 & 0.074 & 0.074 \\
\hline
\end{tabular}

\begin{tabular}{|c|c|c|c|c|c|}
\hline \multicolumn{6}{|c|}{ First Stage Estimation } \\
\hline Distance & $\begin{array}{c}-0.207 * * * \\
(-9.11)\end{array}$ & $\begin{array}{c}-0.227 * * * \\
(-8.33)\end{array}$ & $\begin{array}{c}-0.057 * * * * \\
(-2.83)\end{array}$ & $\begin{array}{c}-0.148 * * * \\
(-6.34)\end{array}$ & $\begin{array}{c}-0.040 * * * * \\
(-3.29)\end{array}$ \\
\hline F- Statistic & $11.28 * *$ & $15.77 * * *$ & $8.50 *$ & $12.22 * *$ & 7.54* \\
\hline
\end{tabular}

PANEL B: Using people who did not have previous experience with the police

\begin{tabular}{|c|c|c|c|c|c|}
\hline $\begin{array}{l}\text { Did not Have } \\
\text { Previous experience }\end{array}$ & $\begin{array}{c}-0.053 * \\
(-1.76) \\
\end{array}$ & $\begin{array}{l}-0.048 * \\
(-1.79) \\
\end{array}$ & $\begin{array}{l}-0.149 * \\
(-1.76) \\
\end{array}$ & $\begin{array}{l}-0.172 * \\
(-1.69) \\
\end{array}$ & $\begin{array}{r}-0.161 * \\
(-1.74) \\
\end{array}$ \\
\hline Observations & 549 & 549 & 549 & 549 & 549 \\
\hline R-squared & 0.0518 & 0.0518 & 0.0518 & 0.0518 & 0.0518 \\
\hline
\end{tabular}

\begin{tabular}{|c|c|c|c|c|c|}
\hline \multicolumn{6}{|c|}{ First Stage Estimation } \\
\hline Distance & $\begin{array}{c}-0.244 * * * \\
(-13.13) \\
\end{array}$ & $\begin{array}{c}-0.269 * * * \\
(-10.61)\end{array}$ & $\begin{array}{c}-0.087 * * * \\
(-5.62)\end{array}$ & $\begin{array}{c}-0.179 * * * \\
(-10.28)\end{array}$ & $\begin{array}{c}-0.081 * * * \\
(-8.84)\end{array}$ \\
\hline F - Statistic & 23.59*** & $18.22 * * *$ & $8.97 *$ & $11.64 * *$ & $11.21 * *$ \\
\hline
\end{tabular}

Notes: *,**, and *** respectively indicate significance levels at the $10 \%, 5 \%$, and $1 \%$ levels. Significant results (at $10 \%$ level or better) are in boldface.

Moreover, depending on the results of the previous experience with the police, people might trust the police in a different way. In order to deal with this we have run our exercise subdividing the sample into people have had a Previous Experience with Police high rated and people who have had a bad previous experience.

As can be seen on Table 6, in both cases little impact occurs. Thus it seems that if people were to somehow become more familiar with police work they would likely attribute less weight to police responsibility in crime rate variations. This seems, however, not to depend on the results of their past personal experiences. 
Table 6 - Regressions for Trust in the Police using Subsamples of People who Have Previous Experience with the Police and Were Satisfied $\backslash$ Were Not Satisfied

\begin{tabular}{|c|c|c|c|c|c|}
\hline & $\begin{array}{l}\text { Total } \\
\text { Crimes }\end{array}$ & Private Property Crimes & $\begin{array}{l}\text { Drug traffic } \\
\text { Incidence }\end{array}$ & Life Crimes & $\begin{array}{c}\text { Rape } \\
\text { Incidence }\end{array}$ \\
\hline \multicolumn{6}{|c|}{ PANEL A: Using people who have had previous experience with the police and were satisfied } \\
\hline Had Previous Experience & $\begin{array}{l}-0.028 \\
(-0.60)\end{array}$ & $\begin{array}{l}-0.026 \\
(-0.59)\end{array}$ & $\begin{array}{l}-0.109 \\
(-0.57)\end{array}$ & $\begin{array}{l}-0.035 \\
(-0.58)\end{array}$ & $\begin{array}{l}-0.277 \\
(-0.59)\end{array}$ \\
\hline Observations & 249 & 249 & 249 & 249 & 249 \\
\hline R-squared & 0.0408 & 0.0408 & 0.0408 & 0.0408 & 0.0408 \\
\hline \multicolumn{6}{|c|}{ First Stage Estimation } \\
\hline Distance & $\begin{array}{c}-0.245 * * * \\
(-8.31) \\
\end{array}$ & $\begin{array}{c}-0.267 * * * \\
(-7.58) \\
\end{array}$ & $\begin{array}{c}-0.063 * * \\
(-2.24) \\
\end{array}$ & $\begin{array}{c}-0.196 * * * \\
(-6.39) \\
\end{array}$ & $\begin{array}{l}-0.025 \\
(-1.46) \\
\end{array}$ \\
\hline F test & $8.55 *$ & $7.55 *$ & 2.41 & $5.50 *$ & 1.41 \\
\hline \multicolumn{6}{|c|}{ PANEL B: Using people who did not have previous experience with the police and were not satisfied } \\
\hline $\begin{array}{l}\text { Did not Have } \\
\text { Previous Experience }\end{array}$ & $\begin{array}{l}0.008 \\
(0.12) \\
\end{array}$ & $\begin{array}{r}0.007 \\
(0.11) \\
\end{array}$ & $\begin{array}{l}0.016 \\
(0.11) \\
\end{array}$ & $\begin{array}{l}0.012 \\
(0.11) \\
\end{array}$ & $\begin{array}{l}0.022 \\
(0.11)\end{array}$ \\
\hline Observations & 146 & 146 & 146 & 146 & 146 \\
\hline R-squared & 0.0276 & 0.0276 & 0.0276 & 0.0276 & 0.0276 \\
\hline \multicolumn{6}{|c|}{ First Stage Estimation } \\
\hline Distance & $\begin{array}{c}-0.202 * * * \\
(-5.07) \\
\end{array}$ & $\begin{array}{c}-0.216 * * * \\
(-4.10) \\
\end{array}$ & $\begin{array}{c}-0.101 * * * \\
(-3.38) \\
\end{array}$ & $\begin{array}{c}-0.130 * * * \\
(-3.35) \\
\end{array}$ & $\begin{array}{c}-0.073 * * * \\
(-3.72) \\
\end{array}$ \\
\hline F - Statistic & $6.14 *$ & $4.84 *$ & 2.85 & 3.92 & 3.56 \\
\hline
\end{tabular}

or better) are in boldface.

\section{Does Skin Color Matter?}

If previous experience with the police is a condition that relates crime rates to success of police work then we should expect that two different subpopulations with exposures to high crime rates would attribute different rates to police work, depending on its efficiency. On the other hand, if crime rates for the two different subpopulations are very similar then we should expect that trust levels in police are quite similar. If this is not the case it could be due to differences in sample demographic profile, or because of different treatment by the police.

Table 7 shows that neighborhoods near police stations where black persons and non-blacks live have very similar crime rates. Despite this, police trust is remarkably higher for the subpopulation of non-black persons than for that of black persons. As mentioned in the last paragraph this is a case of different demographic profiles. Erro! Fonte de referência não encontrada. shows that the black subsample is younger, less schooled, and slightly poorer than non-blacks.

We decided to run the Two Least Stage Regressions of Trust in the Police on different kinds of per capita crime rates separately for the subpopulations of non-black persons and black persons. In these regressions we control for demographic and socioeconomic variables that could differentiate the groups in the ways described on Erro! Fonte de referência não encontrada.. Even after controlling for such characteristics, black persons and non-black persons were still 
different in their perceptions of relationships between crime rates and trust in police; this must be due to the kind of treatment that they receive from the police.

Table 7 - 2SLS Regressions for Trust in the Police using Black and Non-Black Subsamples

\begin{tabular}{|c|c|c|c|c|c|}
\hline & Total Crimes & $\begin{array}{c}\text { Private Property } \\
\text { Crimes }\end{array}$ & $\begin{array}{l}\text { Drug traffic } \\
\text { Incidence }\end{array}$ & Life Crimes & Rape Incidence \\
\hline \multicolumn{6}{|c|}{ PANEL A: Using Black Subsample } \\
\hline Black & $\begin{array}{l}-0.081 * \\
(-1.90)\end{array}$ & $\begin{array}{c}-0.075 * \\
(-1.87)\end{array}$ & $\begin{array}{l}-0.244 * \\
(-1.83)\end{array}$ & $\begin{array}{l}-0.210 * \\
(-1.81)\end{array}$ & $\begin{array}{l}-0.249 * \\
(-1.87)\end{array}$ \\
\hline Observations & 412 & 412 & 412 & 412 & 412 \\
\hline$\underline{\mathrm{R} \text {-squared }}$ & 0.029 & 0.029 & 0.029 & 0.029 & 0.029 \\
\hline \multicolumn{6}{|c|}{ First Stage Estimation } \\
\hline Distance & $\begin{array}{c}-0.210 * * * \\
(-8.62) \\
\end{array}$ & $\begin{array}{c}-0.228 * * * \\
(-6.51) \\
\end{array}$ & $\begin{array}{c}-0.070 * * * \\
(-3.14) \\
\end{array}$ & $\begin{array}{c}-0.155 * * * \\
(-6.46) \\
\end{array}$ & $\begin{array}{c}-0.068 * * * \\
(-5.00) \\
\end{array}$ \\
\hline$\underline{F-\text { Statistic }}$ & $13.27 * *$ & $11.35 * *$ & 8.78* & $10.65 * *$ & $7.91 *$ \\
\hline \multicolumn{6}{|c|}{ PANEL B: Using Non-Black Subsample } \\
\hline Non-Black & $\begin{array}{l}-0.033 \\
(-1.13) \\
\end{array}$ & $\begin{array}{l}-0.030 \\
(-1.13) \\
\end{array}$ & $\begin{array}{l}-0.104 \\
(-1.11) \\
\end{array}$ & $\begin{array}{l}-0.045 \\
(-1.09) \\
\end{array}$ & $\begin{array}{l}-0.131 \\
(-1.11) \\
\end{array}$ \\
\hline Observations & 544 & 544 & 544 & 544 & 544 \\
\hline R-squared & 0.0125 & 0.0125 & 0.0125 & 0.0125 & 0.0125 \\
\hline \multicolumn{6}{|c|}{ First Stage Estimation } \\
\hline Distance & $\begin{array}{c}-0.238 * * * \\
(-13.46) \\
\end{array}$ & $\begin{array}{c}-0.262 * * * \\
(-12.17) \\
\end{array}$ & $\begin{array}{c}-0.077 * * * \\
(-5.11) \\
\end{array}$ & $\begin{array}{c}-0.175 * * * \\
(-10.04) \\
\end{array}$ & $\begin{array}{c}-0.061 * * * \\
(-6.83) \\
\end{array}$ \\
\hline $\mathrm{F}$ - Statistic & $23.28 * * *$ & $19.43 * * *$ & $8.89 *$ & $12.19 * *$ & $8.77 *$ \\
\hline
\end{tabular}

As can be seen on Table 7, crime rates seem to affect trust in the police only for the black subsample, who already on average tend to trust the police less. These results are much stronger than those obtained for the entire sample, which is quite interesting. It is not possible to state with certainty that this result derives from racial stereotyping by the police. But the results do indicate that if trust in the police is an important aspect of crime combat, then public policies should pay special attention to interaction with particular groups such as the black population.

These findings are similar to those reported in prior work on trust and trust in the police. Tyler (2005) shows that minority-group members are more distrustful of the police in the US, with black Americans expressing the lowest level of trust. Trust in the police seems to reflect more than simple fear of crime victimization or concern about crime and neighborhood conditions. In New York City, for example, the New York Police Department (NYPD) is widely credited with reducing violent crime to record lows. Nonetheless, New Yorkers, especially minorities, express widespread discontent with the police (McArdle and Erzen, 2001).

\section{Conclusions}

In the present article we discuss the issue of trust in the police, associating information on crime rates to the geographic location of the respondents. Acurate predictors of trust in the police may constitute an important tool for raising the expected cost of committing a crime. 
In order to achieve this, we have deployed a Two Least Square approach for dealing with the simultaneity bias problem between crime rates and trust in the police. We use the euclidian distance of each informant of the survey to the closest police station as the instrument. Our results point to a negative relation between increases in crime rates and trust in the police. Such results are even stronger for less common crimes such as drug dealing and rape. We also showed that those respondents who had had previous experiences with the police do not seem to associate police work with crime rates. This holds true even when the previous experience with the police received was poorly evaluated. These latter results stand in stark contrast to the respondents who lack any previous experience with the police.

Finally, we did not observe considerable differences in crime rates depending on the availability of police stations, controlling for black and non-black residential areas. Despite this, black people tend to trust the police far less than do non-blacks. This suggests a problem of racial stereotyping that merits further attention.

\section{References}

ACEMOGLU, D.; JOHNSON, S; ROBINSON, J. A. The Colonial Origins of Comparative Development: An Empirical Investigation. American Economic Review, v. 91, p. 13691401, 2001.

ANGRIST, J. D., PISCHKE, J. S. Mostly Harmless Econometrics. Princeton University Press, New Jersey, 2009.

BECKER, G. S. Crime and Punishment: An Economic Approach. Journal of Political Economy, University of Chicago Press, v. 76, p. 169 -175, 1968.

HAYASHI, F. Econometrics. Princeton, NJ: Princeton University Press, 2000.

JESILOW, P.; MEYER, J.; NAMAZZI, N. Public Attitudes toward the Police. American Journal of Police, v.14, p. 67-88, 1995.

MCARDLE, A., ERZEN, T. Zero tolerance: Quality of life and the new police brutality in New York City. New York: New York University Press, 2001.

MOORE, M. Legitimizing criminal justice policies and practices. FBI Law

POVEY, K. Open all hours: A thematic inspection report on the role of police visibility and accessibility in public reassurance. London: Her Majesty's Inspectorate of Constabulary, 2001.

REISIG, M. D.; PARKS, R. B. Experience, quality of life, and neighbourhood context: A hierarchical analysis of satisfaction with police. Justice Quarterly, v. 17, n. 3, p. 607-630, 2000 .

Can community policing help the truly disadvantaged? Crime and Delinquency, v. 50, n. 2, p. 139-167, 2004. 
REN, L.; CAO, L.; LOVRICH, N.; GAFFNEY, M. Linking confidence in the police with the performance of the police: Community policing can make a difference. Journal of Criminal Justice, vol. 33, p. 55-66, 2005.

ROSENBAUM, D. Police innovation post 1980: Assessing effectiveness and equity concerns in the information technology era. IPV Review, v. 1, p. 11-44, 2007.

SAMPSON, R.; JEGLUM-BARTUSCH, D. Legal cynicism and (subcultural) tolerance of deviance: The neighbourhood context of racial differences. Law \& Society Review, v. 2, n. 4, p. 777-804, 1998.

VELEZ, M. B. The role of public social control in urban neighborhoods: A multi-level analysis of victimization risk. Criminology, vol. 39, p. 837-864, 2001.

WAISELFISZ, J. J. Mapa da Violência: Os novos padrões da violência homicida no Brasil. São Paulo, Instituto Sangari, 2012.

WEITZER, R. Citizens' perceptions of police misconduct: Race and neighborhood context. Justice Quarterly, v. 16, p. 819-846, 1999.

WEITZER, R.; TUCH, S. Perceptions of racial profiling. Criminology, v. 40, p. 435-456, 2002. p. $305-325,2004 a$. Race and perceptions of police misconduct. Social Problems, v. 51, Racially biased policing: Determinants of citizen perceptions. Social Forces, v. 83, p. 1009-1030, 2004 b.

WEITZER, R.; TUCH, S.; SKOGAN, W. G. Police-community relations in a majority black city. Journal of Research in Crime and Delinquency, v. 45, p. 398-428, 2008.

WOOLDRIDGE, J. M. Econometric Analysis of Cross-Section and Panel Data. MIT Press, Massachusetts, Second Edition, 2010.

XU, Y.; FIEDLER, M. L.; FLAMING, K. H. Discovering the impact of community policing: The broken windows thesis, collective efficacy, and citizens' judgment. Journal of Research in Crime and Delinquency, v. 42, p. 147-186, 2005. 